\title{
Delta tripod robot FDM típusú 3D nyomtató tervezése Open-Source Arduino fejlesztőplatform felhasználásával
}

\author{
Templom Tamás \\ Mechatronikai Tanszék \\ Debreceni Egyetem, Müszaki Kar \\ Debrecen, Magyarország \\ templomtamas@gmail.com
}

\author{
Erdei Timotei István \\ Mechatronikai Tanszék \\ Debreceni Egyetem, Müszaki Kar \\ Debrecen, Magyarország \\ timoteierdei@eng.unideb.hu
}

\author{
Dr. habil. Husi Géza \\ Mechatronikai Tanszék \\ Debreceni Egyetem, Müszaki Kar \\ Debrecen, Magyarország \\ husigeza@eng.unideb.hu
}

\begin{abstract}
Absztrakt - A 3D nyomtatás ipari felhasználása a gyors prototípusgyártásban teljesedik ki. Legfőbb előnye, hogy lehetővé teszi a tervezők számára, hogy rövid idő alatt prototípust hozzanak létre, mely tesztelhető és gyorsan átalakítható, jelentősen csökkentve ezzel a prototípusfázisból a végtermékig eltelt időt és pénzt. Ugyanakkor, alkalmazásával olyan precíz és komplex formák állíthatóak elő, melyek a hagyományos megmunkálási eljárásokkal (forgácsolás) csak rengeteg idő és hulladék keletkezésével lehetségesek.
\end{abstract}

Kulcsszavak - 3D nyomtató; Delta tripod; Rapid prototyping; Arduino; Marlin; megfogó

\section{BEVEZETÖ}

A Debreceni Egyetem, Épületmechatronikai Kutat Központja add helyet számos az Müszaki Karon zajló belső fejlesztésnek [14]. Ezen egyetemi belső fejlesztések szolgálnak inspirációul további kutatásokhoz, mint az IoT alapú FDM 3D nyomtató [15].Az egyetemi tanulmányaim során többször olyan probléma merült fel egy kisebb projekt elkészítése során, hogy a szükséges mechanikai elemek beszerzése, vagy hagyományos technológiákkal való elkészítése igen bonyolult és költséges lenne. Azonban a CAD szoftverek és az 1980-as években megjelenő gyors prototípus gyártási technológiák alkalmazásával ezen egyedi alkatrészek megtervezése és elkészítése költséghatékonyan és gyorsan megvalósítható. Ezért e probléma kiküszöbölése érdekében merült fel az ötlet egy FDM típusú 3D nyomtató elkészítésére. Azonban a hagyományosnak számító cartesian nyomtatókkal ellentétben az ugyancsak a 80-as években megjelenő delta mechanizmussal működő nyomtató tervezését tűztem ki célul, megfelelő kihívást érezvén a projekttel kapcsolatban. Ugyanis a párhuzamos mechanizmussal müködő delta robotok kinematikai leírása, és ebből adódóan kalibrálása igen bonyolult, hosszadalmas feladat. A nyomtató megtervezését és építését a 2016/17/2 félévben kezdtem, és lehetőséget kaptam a Debreceni Egyetem Tehetséggondozó Programjában (DETEP) való részvételre.

\section{TERVEZÉSI SZEMPONTOK}

A tervezési szempontok közül a legfontosabb a költséghatékonyság volt, többek között ezért is esett a választás az Open-Souce Arduino platform alkalmazására [1]. Vezérlőszoftverként, az Arduino-ra telepített, speciálisan delta 3D nyomtatókhoz tervezett Marlin elnevezésü firmware lett kiválasztva [2]. A vezérlő és szeletelő programok USB kábel segítségével soros porton keresztül kommunikálnak. A delta tripod robotoknál előforduló két mozgástípus (radiális, lineáris) közül a lineárisra esett a választás [3]. Továbbá egy olyan munkaterület kialakítása volt a cél, amelynek mérete elegendő általános célú alkatrészek készítéséhez. A lineáris delta tripod robotok sajátossága a három, egymástól $60\left[{ }^{\circ}\right]$-al elforgatott, függőlegesen álló tengely, így a meghajtást három motor végzi. Irodalomban talált összehasonlítások alapján a bordásszíj meghajtás került kiválasztásra, mivel nagy sebességet tesz lehetővé, ugyanakkor általános célú nyomtatásokhoz elegendő pontosság érhető el alkalmazásával [4].

A meghajtáshoz $2\lceil\mathrm{~mm}\rceil$ fogosztású GT2-es bordásszíj és 20 fogas bordásszíj tárcsa került kiválasztásra, melyeket hibrid léptetőmotorok hajtanak meg. A motorválasztás a Nema 17 típusú bipoláris léptetömotorra esett, aminek méretei 42,3 x 42,3 x 34 [mm] [5]. A szánszerkezetek 2-2 darab $\emptyset 8$ [mm] átmérőjü köracélon futnak, melyekhez lineáris csapágyakkal csatlakoznak.

Ahhoz, hogy a hotend a nyomtatási terület egészét elérhesse, öt paraméter megválasztása volt szükséges: a tengelyek magasságára $(H)$, a delta sugarára $(D R)$, amely a három tengely által bezárt kör sugara, illetve a tolórudak hosszára $(L)$, amely a szánt és az effectort összekötő szakasz, az effector ofszetje (EO), illetve a szán ofszetje (SZO).

Szánszerkezetnek egy Open-Source STL fájl megosztó portálról letöltött, ABS anyagból nyomtatott, LM8UU típusú csapágyakhoz és GT2-es bordásszíjhoz tervezett alkatrész lett választva [6]. Egy tolórúd egy karboncsőből áll, amelynek mind a két végén gombcsuklók helyezkednek el. A termoplasztikus anyag megolvasztásáért felelős hotendnek az E3D V6 típus lett választva. Ahhoz, hogy a hotend a tolórudakhoz csatlakozhasson, egy adapterre, az ún. effectorra van szükség, ehhez csatlakozik a hat darab tolórúd, illetve 
maga a hotend is. Mivel az MK2Y típusú, $\mathrm{d}=220$ [mm] átmérőjü fütött ágy került kiválasztásra, a mérete meghatározza a nyomtatási sík területét. $Z$ tengely mentén pedig a $110[\mathrm{~mm}]-$-es magasság elérése volt a kitüzött cél.

A 1. ábrán jól látható, hogy a három ismeretlen érték $(H, D R$, $L)$ nagyban függ egymástól. Minél nagyobb a delta sugara, annál hosszabb tolórudakra van szükség a $\mathrm{X}-\mathrm{Y}$ síkon való megfelelő tartomány eléréséhez, a tolórudak növelésével azonban elengedhetetlen a tengelyek hosszának növelése is a Z tengely menti mozgási tartomány megtartásához. A ,home” pozícióba küldött robot tolórúdjainak vízszintessel bezárt szöge: $\alpha$. Azonban a mozgás során a tolórudak vízszintessel bezárt szöge nem csökkenhet $20^{\circ}$ alá, így e végállásban lévő szög: $\gamma$.

- $\quad S Z O_{z}=20[\mathrm{~mm}]$

- $H E O_{z}=60[\mathrm{~mm}]$

$$
\begin{gathered}
{[L * \cos (\gamma)+S Z O+E O]} \\
-[L * \cos (\alpha)+S Z O+E O]=110 \\
[L * \cos (\gamma)]-[L * \cos (\alpha)]=110] \\
Z \_ \text {max }=H-S Z O \_Z-H E O \_Z-(L * \sin (\alpha))
\end{gathered}
$$

1. táblázat: Meghatározott fizikai paraméterek

\begin{tabular}{|c|c|}
\hline Alkatrész & Meghatározott méret \\
\hline Tolórúd hossza $[\mathrm{mm}]$ & 336 \\
\hline Delta sugara $[\mathrm{mm}]$ & 260,75 \\
\hline Tengelyek magassága $[\mathrm{mm}]$ & 460 \\
\hline
\end{tabular}

A költségek csökkentése érdekében több alkatrészt is fából készült, az alsó-és felső tálcák, valamint a tengelyek rögzítésére használt támasztók. Annak érdekében, hogy a felső tálca súlya ne a tengelyeket terhelje, illetve, hogy az alsó tálca se a talajon helyezkedjen el, 20x20 [mm]-es zártszelvényekböl készült lábakat alkalmazok [16]. Build platformnak borszilikát üveglap lett választva a magas hőmérsékletek miatt, ugyanis igen nagy a mechanikai szilárdsága és a kis hőtágulási együtthatója miatt a hőmérsékletingadozásoknak ellenáll. Maximálisan $500\left[{ }^{\circ} \mathrm{C}\right]$-ig alkalmazható.

A tervezési szempontok meghatározása után az ingyenesen elérhető Autodesk Inventor programban elkészült a szerkezet 3D modellje [7], amely a további tervezéshez elengedhetetlen volt. A modell meglétével vizsgálhatóvá váltak az általam választott, illetve tervezett alkatrészek felhasználhatósága és illeszthetősége. További előnye, hogy szimulációk segítségével ellenőrizhető, ha a mozgások közben ütközések jönnek létre

\section{Az 1. ábrán látható alkatrészlista:}

\section{Alsó tálca}

2. Felső tálca

3. Alsó tengelytámasztó

4. Felső tengelytámasztó

5. Fütött ágy

6. Köracél

7. Tolórúd

8. Hotend

9. Effector

10. Szán

11. Léptetőmotor

12. Extruder motor extrudáló egységgel

13. Szíjtárcsa

14. Vezérlő elektronika

15. Zártszelvény lábak

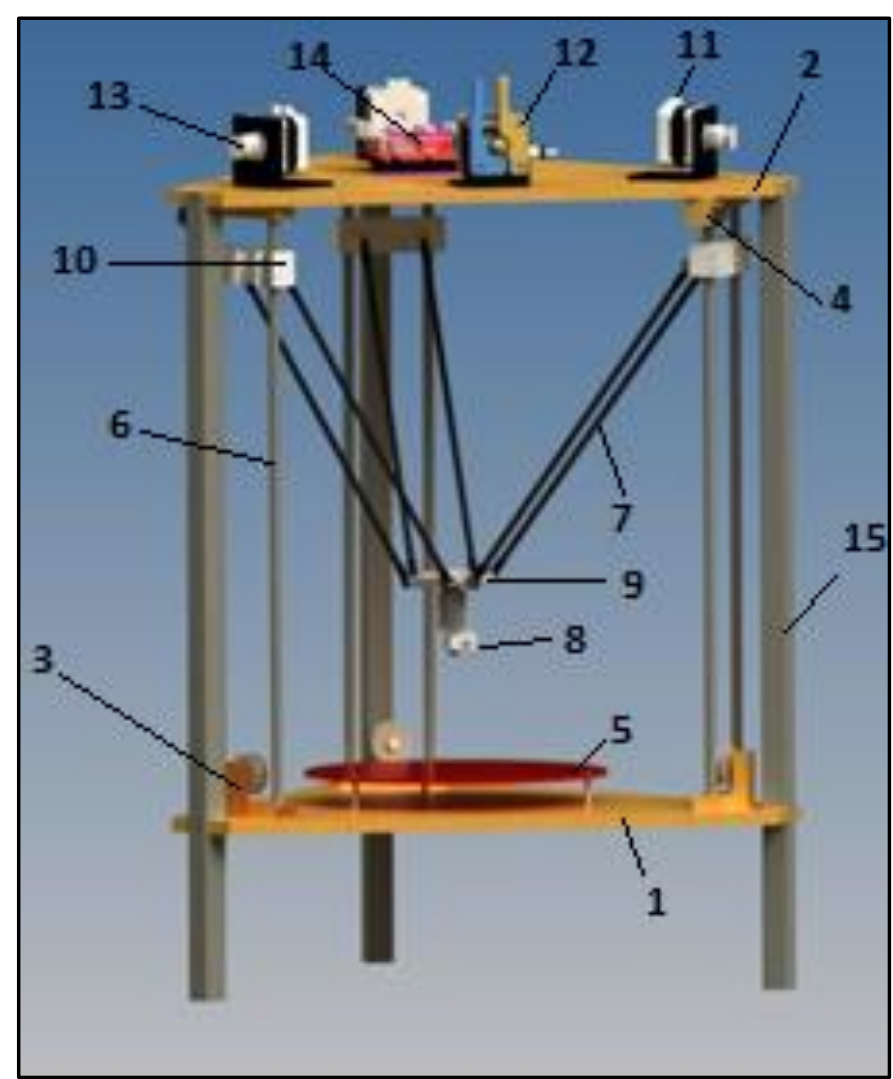

1. ábra - Autodesk Inventor-ban összeállított 3D modell [7]

A termoplasztikus szál előretolásához a bowdenes megoldás került kivitelezésre, amely azt jelenti, hogy az extruder motor nem közvetlenül a hotend fölött helyezkedik el, hanem távolabb, a felső tálcára rögzítve, így a hotenddel egy tefloncső köti össze, amely a termoplasztikus anyagot megvezeti [17]. Hátránya a nagyobb nyomatékigényü motor, valamint mindig marad filament a csőben, illetve flexibilis anyagok elöretolására alkalmatlan. Előnye pedig a kisebb mozgatott tömeg [4].

Összeszerelés során a bordásszíjak megfelelő feszessége érdekében szíjfeszítő felhelyezése szükséges. Illetve a tolórúdpárokat valamilyen rugalmas összekötő elemmel érdemes összecsatlakoztatni a mechanikai rezgések elnyelése érdekében. 


\section{A MEGÉPÍTETT ÁRAMKÖR}

A megépített mechnaikai vázszerkezet után az elektronikai részek telepítése következik.

A léptetőmotor vezérlök, illetve a további szükséges elektronikák az Arduino Megára shield-ként helyezett Ramsp 1.4-be csatlakoznak, amely egy speciálisan 3D nyomtatókhoz készített eszköz [5]. A shield tápfeszültsége 12 [V] egyenfeszültség, amelyet egy 280 [W]-os ATX tápegység biztosít. Kettő darab 5 [A]-es kimenete található, egy a hotendnek, amely a termoplasztikus anyag megolvasztásáért felelős, valamint egy a ventilátornak, amely a már kiextrudált rétegek hütésére szolgál. Valamint egy darab 11 [A]-es kimenete van, amely a fütött ágy (heated bed) áramellátásához szükséges. Továbbá csatlakoztatható hozzá három darab thermisztor, melyekből $100[\mathrm{k} \Omega]$-osak kerültek használatba, illetve hat darab végálláskapcsoló, melyekböl három van alkalmazva a felső végállásokban, mechanikusan müködtetett, alaphelyzetben nyitott érintkezök formájában. A Ramps 1.4 összesen öt darab léptetőmotor vezérlő integrálásához alkalmas, mivel a mozgáshoz három szükséges, valamint az extrudáláshoz még egy további, így a jövőben még egy extruder motor felszerelhető, mely egy második hotend számára biztosíthatja az anyagáramlást.

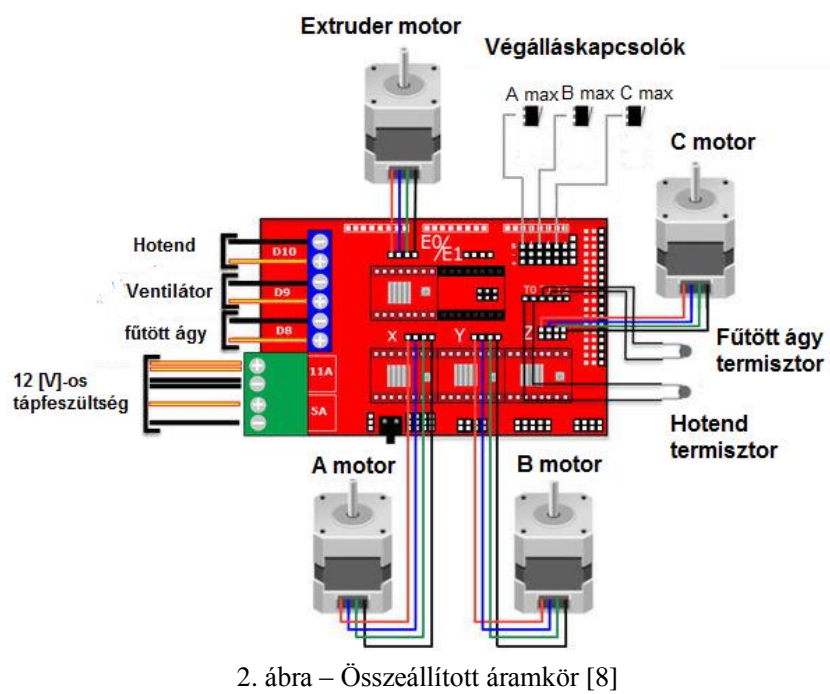

A kiválasztott léptetőmotorok elektrotechnikai adatai: A maximális áram fázisonként 1,3 [A], nyomatékát tekintve: $0,22\lceil\mathrm{Nm}\rceil$, lépésenkénti elfordulás szöge $1,8^{\circ}$. A vezérléséhez szükséges elektronika a DRV825 (Pololu) nevü léptetőmotor vezérlő integrált áramkörbe van integrálva [9]. Ez tartalmazza az áramméréshez szükséges ellenállásokat, valamint a motor tekercsein átfolyó áramot beállító potenciométert.

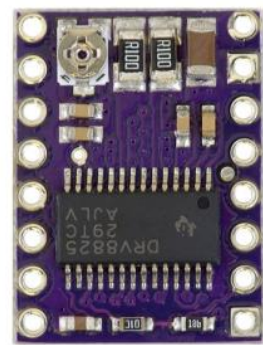

3. ábra: DRV8825 [9]

$\mathrm{Az}$ áramkör egyik legnagyobb előnye az úgynevezett microstep lépésosztás funkció, amellyel a léptetőmotorok egészlépés szögeit bonthatjuk tovább. A microstep-nél megkülönböztetünk 1/2,1/4, 1/8,1/16, 1/32 lépésszögeket az áramkör beállításaitól függöen. A Ramps-en lévő motorvezérlő foglalatoknál jumperekkel állítható be a szükséges microstep []. Mivel a DRV8825-ös vezérlő képes az 1/32 microstepre, így az az érték került beállításra. A Pololu esetében a maximálisan beállítható áram 2,2 [A], és 8-45 [V] között változhat a motorok tápfeszültsége [9].

Ezen adatokból a következő képlettel számolható ki a mozgás felbontása [10]:

$$
\begin{aligned}
& \frac{\text { Steps }}{m m}=\left(\frac{\left(\frac{360^{\circ}}{\text { lépésszög }^{\circ}}\right) *\left(\frac{1}{\text { microstep }}\right)}{\text { szíj fogosztás } * \text { tárcsa fogszám }}\right) \\
& \frac{\text { Steps }}{m m}=\left(\frac{\left(360^{\circ} / 1,8^{\circ} *\left(1 / \frac{1}{32}\right)\right)}{2 * 20}\right)=160
\end{aligned}
$$

\section{KALIBRÁLÁS}

A kalibrálás során megkülönböztethetünk szoftveres, illetve fizikai kalibrálást. A softveres kalibrálás során történik az Arduino program beállítása, illetve a szeletelö szoftver beállításai. A Marlin firmware-ban szükséges megadni a nyomtató fizikai paramétereit, a hajtásra, végálláskapcsolókra és hőmérsékletekre vonatkozó adatokat, valamint a lábkiosztásokat. $\mathrm{Az}$ ingyenes és hivatalos segédlettel rendelkező Ultimaker Cura nevű szeletelőprogramon belül elvégzett beállítások a nyomtatási területre, a vezérlőprogrammal való kommunikációra és a fúvóka átmérőjére vonatkoznak [11]. Valamint itt szükséges beállítani az adott nyomtatásra vonatkozó értékeket, mint a kitöltési tényező, nyomtatási sebesség, illetve a nyomtatandó anyaghoz szükséges hőmérsékleti értékek.

A nyomtató fizikai kalibrálása előtt bizonyos alkatrészek kalibrálása, tesztelése szükséges. Ilyen elemek a végálláskapcsolók, melyek müködését egyesével szükséges ellenőrizni. Továbbá fontos feladat a léptetőmotor vezérlők áramkorlátozásának beállítása. Annak érdekében, hogy a léptetőmotorok a legnagyobb nyomatékot fejthessék ki, olyan léptetőmotor vezérlöt kell alkalmazni, amelyen nagyobb a maximálisan átfolyható áram, mint a léptetőmotor fázisonkénti 
áramértéke. Azonban a motor védelme érdekében limitálni kell a vezérlőn átfolyó áramot, amely maximálisan a motor fázisonként felvett áramával lehet egyenlö. A megfelelően beállított áramlimittel csökkenthetö a motor melegedése, illetve elkerülhető a lépésvesztés. A léptetőmotor a vezérlőhöz csak a konfiguráció megléte után kapcsolható. A beállításhoz a vezérlő referenciafeszültségének mérésére van szükség. A DRV8825 típusú vezérlő esetén a következő egyenlőség áll fenn:

$$
I_{\text {limit }}=2 * U_{\text {ref }}
$$

Mivel a választott léptetőmotorok fázisonkénti árama 1,3 [A], így a 6 . képlet alapján beállítandó referenciafeszültség értéke: $U_{\text {ref }}=650[\mathrm{mV}][9]$.

A delta tripod típusú 3D nyomtatók fizikai kalibrálásának első lépése a $\mathrm{P}(0,0,0)$ mechanikai nullpont előzetes, manuális beállítása. A home pozícióba állított robot negatív $\mathrm{Z}$ irányba való mozgatása előtt egy papírlap felhelyezése szükséges az üveglapra, majd addig szükséges mozgatni a szerkezetet, amíg a hotend el nem éri a lapot, de rá nem szorítja az üvegre. Mivel egy papír vastagsága $\approx 0,1[\mathrm{~mm}]$, így az Arduino programban szereplő értéket a megtett elmozdulás és a papír vastagságának összegére szükséges felülírni. Ez az ún. papírteszt. [12].

A delta robotoknál igen gyakran előforduló jelenség az ún. „flatness"-ség, ami azt jelenti, hogy a hotendet a nyomtatási terület szélei felé mozgatva az nem tartja a Z magasságát. Az elmozdulás irányától függően megkülönböztetünk konkáv és konvex íven való mozgást [18]. Meglétének oka általában a programban hibásan megadott delta sugár értéke. A konkáv ív a delta sugár növelésével, a konvex ív pedig annak csökkentésével küszöbölhető ki. A csekély méretü flatness-ség esetben a probléma inkább a szerelés során elkövetett pontatlanságokból adódhat, pl.: a három tengely nem egyforma távolságra helyezkedik el a $\mathrm{P}(0,0,0)$ ponttól. Ebben az esetben a sík mozgás eléréséhez a végálláskapcsolók korrigálása szükséges [12]

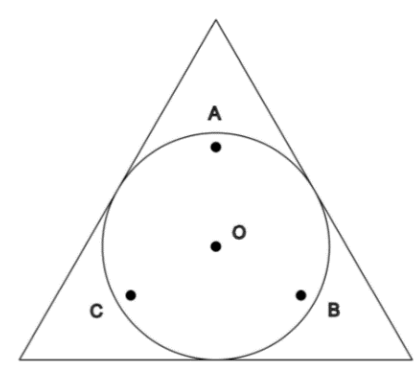

4. ábra: Végálláskorrekciós pontok

A végállás korrigálás során is a papírteszt kerül alkalmazásra. A nyomtatási síkon, a 4. ábra alapján három pont kijelölése szükséges, lehetöleg minél közelebb a három tengelyhez. A folyamat a mechanikai nullpont beállításához hasonló, az adott pontnál addig mozgatandó $\mathrm{Z}$ tengely mentén a hotend, amíg el nem éri a papírlapot. A konvex vagy konkáv ívnek megfelelően a pontra vonatkozó $Z$ koordináta nem 0,1 , hanem attól eltérő érték lesz. A ponthoz tartozó végálláskorrekció értékét a különbség mértékére szükséges beállítani. Majd a home pozícióba való küldés után újra meg kell ismételni a folyamatot, ha újra különbség mutatkozik, akkor a különbség értékét hozzá kell adni a már meglévő korrekcióhoz. A lépés addig ismétlődik egy pont esetében, amíg az eltérés nulla nem lesz. Ezt követően a lépést a másik kettő pont esetében is el kell végezni. Majd előröl kezdeni, és addig ismételni, amíg mind a három pontra vonatkozóan nullára csökken az eltérés mértéke.

Ezt a folyamatot a végállások beállításának finomítása követi. Ehhez egy egyréteg vastag próbatest nyomtatására van szükség, melyen az tengelyekhez legközelebb eső részek rétegvastagságának lemérése szükséges. Ha a mért érték nem egyezik a rétegvastagságnak beállított értékkel, akkor a két érték különbségének nagyságával tovább korrigálandó az adott végállás.

A sík mozgási felület elérése után az tengelyek egymáshoz viszonyított szögeinek beállítása következik. Alapesetben $60-60\left[{ }^{\circ}\right]$-ot zárnak be egymással a tengelyek, azonban a megépítésnél fellépő pontatlanságok következtében néhány fok eltérés tapasztalható. Ehhez a folyamathoz egy próbatest nyomtatása szükséges, amely esetemben egy egyenlöszárú háromszög alapú hasáb. A kinyomtatott modellen lemért három oldal ismeretében cosinus tétel segítségével meghatározható a három szögérték, melyekkel felülírandóak az Arduino firmware-ben található $60^{\circ}$-os értékek.

Mindezek után következhet a dimenziók beállítása, amely kétféleképpen is történhet. Az első lehetőségnél az egyenlő oldalú háromszög alapú hasábot alkalmazzuk. A háromszög magasságainak mérésével az adott tengelyekhez tartozó irányokat vizsgálom, információt kapva arról, hogy mely tengellyel lehet valamilyen méretet befolyásoló probléma (Pl.: nem megfelelően feszített szíj).

A próbatest lehet még kocka is, azonban mindkét esetben az elvárt és a mért méretek hányadosával, az Arduino programban szereplő koordináta transzformációs értéket kell megszorozni. Bármely próbatestet is választjuk, a kalibrációs lépéseket újra, a legelejétől ismételni szükséges, amíg mindenben megfelelö eredményt nem kapunk.

A kalibrálás során az értékek megváltoztatását az Arduino programon belül kell megvalósítani, amely a folyamatos újra feltöltések miatt igen lelassítja az így is lassú folyamatot.

\section{REFERENCIAMUNKÁK}

A kalibrációs próbatestekkel végzett tesztelések során a következő eredmény alakult ki:

- $\mathrm{Az} X$ és $Z$ tengelyek mentén minimális eltérés tapasztalható, azonban az Y tengely mentén 20 [mm] esetén $-0,1[\mathrm{~mm}]$ eltérés mérhető.

- $80[\mathrm{~mm} / \mathrm{s}]$ nyomtatási sebesség mellett még szakadás nélküli kitöltési tényező nyomtatható.

A megfelelő minőséget elérve különböző alkatrészek 3D nyomtatása következett. A nyomtatási minőség növelése érdekében elkészítésre került egy, a már kiextrudált anyagot hütő ventilátor fúvókája, illetve tartószerkezete. Készült a 
szíjak feszességét elösegítő szíjfeszítő, illetve a termoplasztikus szál dobszerkezetének forgását segítő csapágyakkal ellátott szerkezet.

Lehetőséget kaptam a Debreceni Egyetem Müszaki Karának Mechatronikai Tanszékén található KUKA KR5 típusú ipari robothoz, egy hallgatótársam, Varga Viktor által tervezett, háromujjú megfogó szerkezet bizonyos alkatrészeinek kinyomtatására. Az elkészítéshez 1,75 [mm] átmérőjü PLA anyag lett kiválasztva, a 2. táblázatnak megfelelően el lett végezve a hőmérsékleti beállítás a szeletelő programban.

Kinyomtatásra került a megfogást végző három darab uij, illetve a motor nyomatékát az ujjaknak átadó elemek: a tolórudak és a forgatóelem. Valamint egy rögzítőelem, amelyen a szerszám tárolódhat szerszámcsere idején. A nyomtatások

$0,2[\mathrm{~mm}]$-es rétegvastagsággal, 30 [\%] kitöltési tényezővel és $50[\mathrm{~mm} / \mathrm{s}]$-os sebességgel készültek.

2. táblázat: PLA nyomtatási hőmérséklet [13]

\begin{tabular}{|c|c|}
\hline Hotend hőmérséklet $\left[{ }^{\circ} \mathrm{C}\right]$ & 185 \\
\hline Fütött ágy hőmérséklet $\left[{ }^{\circ} \mathrm{C}\right]$ & 60 \\
\hline
\end{tabular}

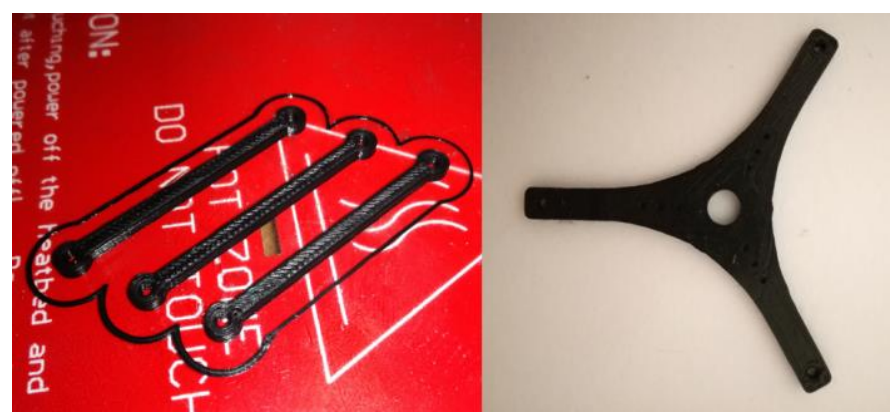

5. ábra: A tolórudak és a forgatóelem

A tolórudak nyomtatási ideje: 3 [perc/db], a forgatóelemé pedig 10 [perc]

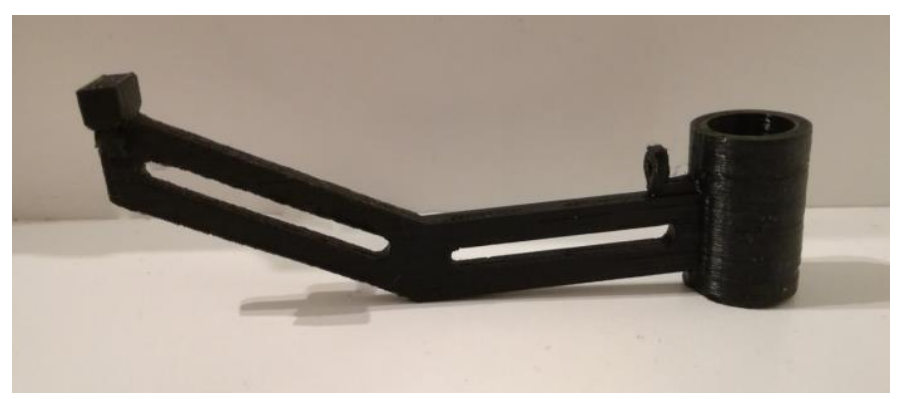

6. ábra: A megfogószerkezet ujja

Az ujjak nyomtatási ideje: 85 [perc/db], nyomtatás során támaszanyagot igényelt, és a tartóelemé pedig 163 [perc]. A felsorolt alkatrészek összesített nyomtatási ideje nem haladja meg a 8 órát, összesített tömegük pedig 52,2 [g].

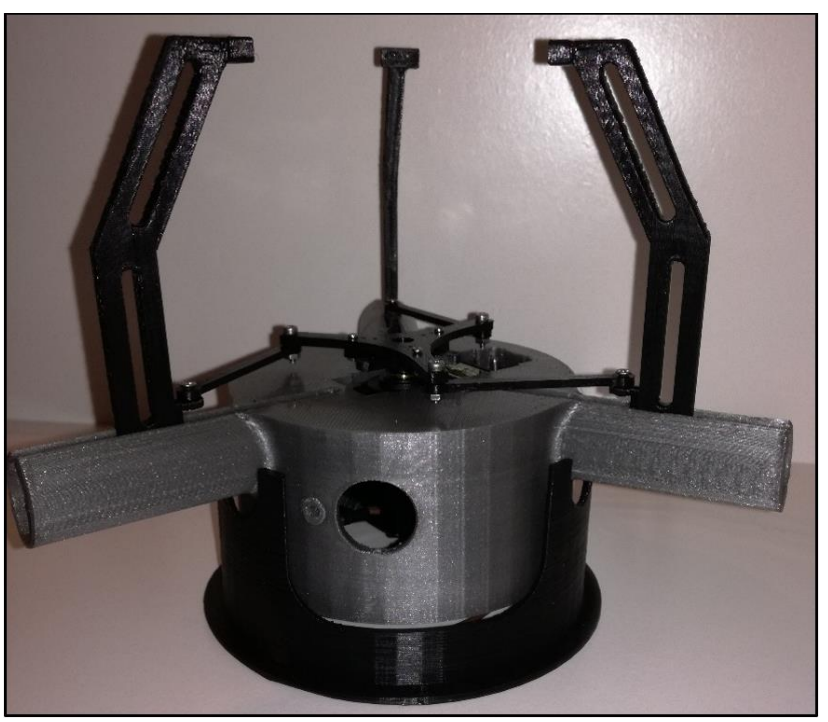

7. ábra: A kész megfogó a tartóelemen

\section{KONKLÚZIÓ}

A tervezést követően elkészítettem a nyomtató mechanikai vázszerkezetét illetve elvégeztem az elektronikai részek telepítését. $\mathrm{Az}$ alkalmazott programokon elvégzett beállításokat követően a dolgozatom során a legnagyobb kihívást jelentő kalibrációs eljárásokat végigjárva megbizonyosodtam a nyomtató sikerességét illetően. Az elméleti háttér ismeretét követően a próbanyomtatások során a gyakorlatban is sikeresen megismertem az FMD 3D nyomtatási technológia sajátosságaival. A KUKA KR5 típusú robothoz készített háromujijú megfogószerkezet kinyomtatásával pedig bebizonyítottam a szerkezet gyors prototípusgyártásra való alkalmasságát.

A dolgozat elkészítését követően a következő továbbfejlesztési lehetőségek merültek fel:

- A zártszelvényből és fa alkatrészekből álló mechanikai vázszerkezet könnyítése és a munkaterület növelése céljából egy új, alumínium zártszelvényekből valamint általam tervezett és nyomtatott sarokelemekből mechanikai váz elkészítésén dolgozom.

- A kalibrálási eljárás önmagában is igen hosszadalmas folyamat, azonban az értékek változtatása során az Arduino program folyamatos feltöltése még jobban megnöveli a ráfordított idöt. E probléma kiküszöbölése érdekében célommá vált az Arduino program és a szeletelö program közötti kommunikáció kibővítése, mellyel bizonyos értékek ideiglenesen felülíródnak, ezzel csökkentve a kalibráláshoz szükséges idöt.

- Annak érdekében, hogy egy nyomtatás a jelenlétem nélkül is elvégezhető legyen, a nyomtatót hálózatra kötve, egy Linux disztribúciós operációs rendszerrel müködő, Orange Pi elnevezésü Open-Source mini 
számítógép és a szintén Open-Source internetes felület, az Octoprint felhasználásával egy távfelügyeletre és távvezérlésre alkalmas rendszer kialakítása a célom.

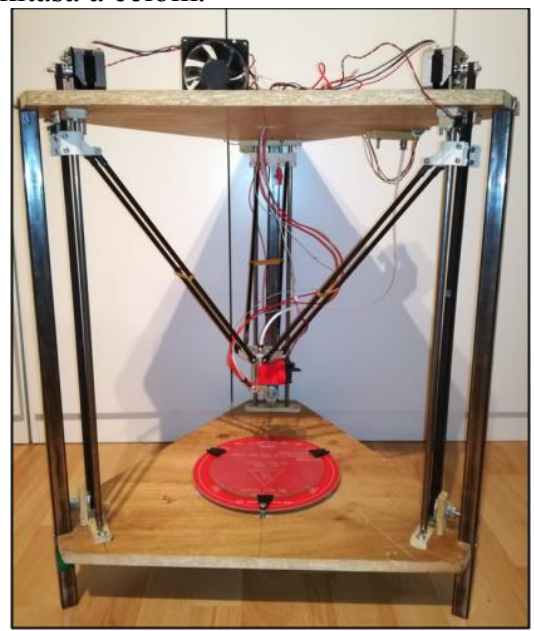

8. ábra - Az elkészített 3D nyomtató

\section{KÖSZÖNETNYILVÁNÍTÁS}

A publikáció elkészítését az EFOP-3.6.1-16-2016-00022 számú projekt támogatta. A projekt az Európai Unió támogatásával, az Európai Szociális Alap társfinanszírozásával valósult meg.

\section{HIVATKOZÁSOK}

[1] Arduino IDE 1.5.7. Elérhető: https://www.arduino.cc/en/Main/OldSoftwareReleases\#previous (2017.10.23)

[2] „Marlin,”[Online]. Available: http://marlinfw.org/. [Hozzáférés dátuma: $27112017]$

[3] S. Glaves, ,Rocholl (Rostock) Style Delta Robot Kinematics”.

[4] R. Santos, J. James, T. Chris, S. Marshall, P. Maalouf, „Delta 3D Printer," 2015

[5] „Reprap,” [Online]. Available: http://reprap.org/wiki/Main_Page. [Hozzáférés dátuma: 2711 2017].

[6] ,Thingiverse,"

[Online].

Available: https://www.thingiverse.com/thing:1495442. [Hozzáférés dátuma: 2711 2017]. https://www.autodesk.com/products/inventor/overview. [Hozzáférés dátuma: 2711 2017].

[8] „Instructables,” [Online]. Available: http://www.instructables.com/id/Complete-newbie-step-by-step-3Dprinter-with-all-p/. [Hozzáférés dátuma: 2911 2017].

[9] „Pololu,” [Online]. Available: https://www.pololu.com/product/2133. [Hozzáférés dátuma: 2711 2017]

[10] .J. Prusa és N. Zadoks, „RepRap Calculator V3,” [Online]. Available: https://nathan7.eu/stuff/RepRapCalculator/RepRapCalculator.html. [Hozzáférés dátuma: 2711 2017].

[11] „Ultimaker Cura,” [Online]. Available: https://ultimaker.com/en/products/ultimaker-cura-software. [Hozzáférés dátuma: 2711 2017].
[12] C. T. Brittain, „Ladvien,” 2014. [Online]. Available: https://ladvien.com/robots/kossel-mini-calibration/. [Hozzáférés dátuma: $27112017]$.

[13] G. Husi és P. Szemes, „Rapid prototyping technológiák - additív technikák," 2015.

[14] Kalmár F, Kalmár T, Csáki I, Husi G „Interrelation between ACH and air temperature distribution in a room," 2009: Proceedings of the 11th International ROOMVENT Conference. Busan, Dél-Korea, 2009.05.242009.05.29. Busan: [s. n.], 2009. pp. 911-917.

[15] T. I. Erdei, ZS. Molnár, G. Husi, ,Selecting Equipment and Supplies for Self-Replicating 3D Printer," Acta Technica Corviniensis - Bulletin of Engineering, Hunedoara9.1, Jan-Mar 2016, pp. 59-62.

[16] T. I. Erdei, Zs. Molnár, N. C. Obinna, G. Husi, „AGV cyber physical navigation system," FMTÜ - XXII. International Scientific Conference of Young Engineers - Kolozsvár, 23-24.03.2017.

[17] T. I. Erdei, Zs. Molnár, N. C. Obinna, G. Husi, „Cyber physical systems in mechatronic research centre," MATEC Web Conf. Volume 126, 2017.

[18] N. C. Obinna, T. I. Erdei, Zs. Molnár, G. Husi, „LabVIEW Motion Planning and Tracking of an Industrial Robotic Manipulator (KUKA KR5 arc): Design, Modelling, and Simulating the Robot's Controller Unit," FMTÜ - XXII. International Scientific Conference of Young Engineers - Kolozsvár, 23-24.03.2017. 